\title{
Tinjauan Yuridis Terhadap Tindak Pidana Pencurian dengan Kekerasan oleh Anak di bawah Umur
}

\author{
Verawati \\ Universitas Pejuang Republik Indonesia, Makassar \\ verawatiwaris@gmail.com
}

\begin{abstract}
Abstrak. Tujuan penelitian ini yaitu : (1). Untuk mengetahui bagaimana Penjatuhan Pidana Terhadap Pelaku Begal Yang Dilakukan Oleh Anak di dawah Umur. (2). Untuk mengetahui faktorfaktor yang menjadi pertimbangan hakim dalam menjatuhkan pidana terhadap pelaku begal yang dilakukan oleh anak di bawah umur. Metode penelitian ini menggunakan jenis penelitian hukum normatif, yaitu dengan mengkaji putusan pengadilan, aturan-aturan hukum, teori-teori hukum dan bahan-bahan hukum yang berhubungan dengan permasalahan yang akan dibahas. Hasil Penelitian yang diperoleh dari penulisan ini yaitu : (1) Wujud pemidanaan terhadap tindak pidana pencurian dengan kekerasan yang dilakukan oleh anak secara bersama-sama dengan nomor putusan 10/Pid.Sus Anak/2015/PN.Mks sudah tepat karena telah memenuhi unsur dalam perkara yang didakwakan oleh Jaksa Penuntut Umum dan Majelis Hakim, serta penjatuhan pidana penjara tidak melebihi dari pidana yang diancam oleh Pasal 365 ayat (2) ke-1 dan ke-2 KUHP dan Pasal 363 ayat (1) ke-4 KUHP, dimana unsur-unsur dalam tindak pidana ini sudah memenuhi karakter dan terbukti. (2) Pertimbangan hukum Hakim dalam menjatuhkan sanksi pidana terhadap anak sebagai pelaku tindak pidana pencurian dengan kekerasan dalam Putusan Nomor : 10/Pid.Sus.Anak/2015/PN.Mks yakni dengan terpenuhinya semua unsur-unsur pasal dalam dakwaannya yaitu Pasal 365 ayat (2) ke-1 dan ke-2 KUHP dan Pasal 363 ayat (1) ke-4 KUHP,dimana berdasarkan alat bukti ditambah keyakinan hakim. Selain itu juga hakim dalam menjatuhkan sanksi pidana harus mempertimbangkan hal-hal yang memberatkan dan meringankan bagi terdakwa.
\end{abstract}

Kata Kunci : Tinjauan Yuridis, Tindak Pidana Pencurian, Anak

Abstract. The purpose of this study are: (1) to find out how the imposition of Crime Against Perpetrators robber ducted by Children Under Age. (2) to determine the factors that are considered by the judge in imposing punishment against the perpetrators robber committed by minors. This research method using normative law research, reviewing the court's decision, rule of law, legal theories, and legal materials related to the issues to be discussed. Results obtained from this paper are: (1) the form of punishment against the crime of theft with violence by the child together with decision No.10/Pid.Sus Anak/2015/PN.Mks own right because it has met the elements in cases indicted by the public prosecutor and judges, as well as imposition of imprisonment not exceeding crime punishable by Article 365 paragraph (2) 1st and 2nd penal code and Article 363 paragraph (1) 4th criminal code, in which the elements in offenses already meet the character and proven. (2) Consideration law judge in imposing criminal sanctions against children as perpetrators of the crime of theft with violence in No.10/Pid.Sus Anak/2015/PN.Mks, the fulfillment of all elements of article in indictment, Article 365 paragraph (2) 1st and 2nd penal code and Article 363 paragraph (1) 4th Criminal Code, which is based on evidence plus the judge's conviction. It also judges in imposing criminal sanctions should consider aggravating factors and relieve the defendants.

Keywords: Judicial Review, Crime Theft, Children

\section{PENDAHULUAN}

Makassar merupakan salah satu dari lima kota terbesar di Indonesia. Dalam perkembangannya Makassar mengalami perkembangan yang sangat pesat dalam bidang ekonomi, infrastuktur dan lain sebagainya. Sebagai dampak dari perkembangan tersebut, Makassar menghadapi masalah sosial 
kemasyarakatan yang tidak sedikit pula, dan sebagian besar dari masalah tersebut sebenarnya melanggar dari norma sosial dan hukum positif yang berlaku. Geng motor adalah salah satu masalah baru yang timbul dari efek perkembangan kota makassar. perilaku geng motor yang anggotanya sebagian besar adalah remaja tersebut sudah meresahkan masyarakat.

Geng motor yang berkembang pesat di masyarakat kota Makassar ini sering kali melakukan pelanggaran tindak pidana, diantaranya melanggar peraturan lalu lintas, miras, penyalahgunaan obat terlarang, penganiayaan, perkelahian antar kelompok, bahkan sampai perampokan. Hal ini meresahkan kota Makassar, terlebih bagi orang yang ingin keluar di malam hari. Geng motor memang termasuk Juvenile deliquency atau lebih sering disebut kenakalan remaja. Hal ini sangat memprihatinkan masa depan bangsa dan Negara ini terletak pada kaum muda seperti mereka dan sebagian dari mereka terjebak atau dapat dikatakan ikut dalam kegiatan geng motor yag tidak produktif dan cenderung merugikan ini.

Di indonesia dibuat aturan-aturan perundangan-undangan yang mengatur dan melindungi hak-hak anak yang diratifikasi dari Konvensi Hak Anak (KHA) dengan keputusan Presiden Nomor 36 Tahun 1990. Peraturan perundang-undangan yang dibuat oleh pemerintah antara lain Undang-Undang Nomor 39 Tahun 1999 Tentang Hak Asasi, Manusia, Undang-Undang Nomor 3 Tahun 1997 Tentang Pengadilan Anak yang telah direvisi dengan Undang-Undang Nomor 11 tahun 2012 Tentang Sistem Peradilan Pidana Anak, Undang-Undang Nomor 23 Tahun 2002 Tentang Perlindungan Anak Secara subtansi Undang-Undang tersebut mengatur hak-hak anak yang berupa, hak hidup, hak atas nama, hak pendidikan, hak kesehatan dasar, hak untuk beribadah menurut agamanya, hak berekspresi, berpikir, bermain, berkreasi, beristirahat, bergaul dan hak jaminan sosial.

Sebelum lahirnya Undang-Undang Nomor 23 tahun 2002 Tentang Perlindungan Anak pada dasarnya anak-anak yang bermasalah dikategorikan dalam istilah kenakalan anak, yang mengacu pada UndangUndang Nomor 3 Tahun 1997 Tentang Pengadilan Anak setelah diundangkannya Undang-Undang Perlindungan Anak maka istilah tersebut berubah menjadi anak yang berkonflik dengan hukum $(\mathrm{ABH})$ dan saat ini Undang-Undang nomor 11 tahun 2012 Tentang Sistem Peradilan Pidana Anak menggunakan dengan menggunakan juga istilah anak yang berkonflik dengan hukum.

Kriminolog dari Universitas Indonesia, Hamidah Abdurrahman, mengatakan dalam Kitab Undang-undang Hukum Pidana terdapat beberapa jenis pencurian. Menurut dia, dalam KUHP juga mengatur sanksi berbeda bagi setiap jenis pencurian. Menurut hamidah, pencurian dalam KUHP dibagi dalam 6 pasal, yaitu Pasal 362 sampai 367. Pasal 362, yang digunakan polisi untuk menjerat pelaku pencurian biasa. Pencurian dengan unsur pemberatan ialah seperti pencurian ternak, pencurian yang dilakukan pada waktu kebakaran, letusan, banjir, gempa bumi, atau gempa laut, gunung meletus, kapal karam, kapal terdampar, kecelakaan kereta api, huru hara, pemberontakan atau bahaya perang, pencurian pada waktu malam dalam sebuah rumah atau pekarangan tertutup yang ada rumahnya, serta pencurian yang dilakukan oleh orang yang ada disitu tidak diketahui atau tidak dikehendaki oleh yang berhak (Suwarso, http://tempo.com, diakses tanggal 25 Februari 2015).

Anak sebagai individu yang belum dewasa perlu mendapatkan perlindungan hukum/yuridis (legal protection) agar terjamin kepentingannya sebagai anggota masyarakat. Masalah menegaskan hak-hak anak dan hukum anak, pada dasarnya sama dengan masalah penegakan hukum secara keseluruhan. Berdasarkan uraian diatas penulis hendak mendalami apakah penjatuhan pidana tehadap terhadap anak tersebut telah diterapkan sesuai perundang-undangan yang berlaku dan mempertimbangkan hak-hak anak pelaku tindak pidana tersebut. Karena penjatuhan pidana tersebut akan menentukan masa depan anak tersebut. 


\section{METODE PENELITIAN}

Jenis penelitian yang digunakan adalah penelitian hukum normatif (Soekanto, 2013), yaitu dengan mengkaji putusan pengadilan, aturan-aturan hukum, teori-teori hukum dan bahan-bahan hukum yang berhubungan dengan permasalahan yang akan dibahas. Pendekatan yang digunakan dalam penelitian ini, yaitu pendekatan perundang-undangan (statue approach) (Marzuki, 2010:96). Dalam konteks ini, ketentuan-ketentuan yang akan ditelaah dan dikaji adalah beberapa instrumen hukum nasional yang berkaitan dengan perkara anak sebagai pelaku tindak pidana. Selain menggunakan statue approach, digunakan juga pendekatan konseptual (conceptual approach). Adapun yang dimaksud pendekatan konseptual (Soekanto, 2013:137), adalah pendekatan yang beranjak dari pandangan-pandangan dan doktrindoktrin yang berkembang dalam ilmu hukum khususnya pada lapangan hukum nasional. Pandangan-pandangan, doktrin-doktrin yang akan digunakan dalam penelitian ini, memiliki keterkaitan erat dengan perkara anak sebagai pelaku tindak pidana.

Teknik pengumpulan data yang dilakukan dalam penelitian ini dilakukan dengan penelitian kepustakaan (library research), yang mempelajari dan mengkaji sejumlah ketentuan-ketentuan hukum nasional, buku-buku teks, kamus-kamus hukum, jurnal-jurnal hukum yang dianggap relevan dengan objek penelitian (Keraf, 2004). Dalam penelitan hukum normatif, maka sumber data yang digunakan adalah bahanbahan hukum, yang terdiri dari (Salim, 2013):

1) Bahan Hukum Primer adalah bahan hukum yang memiliki kekuatan mengikat, meliputi beberapa instrumen hukum nasional yang berkaitan dengan kajian dalam tesis ini.

2) Bahan hukum sekunder adalah bahan hukum yang memberikan penjelasan mengenai bahan hukum primer, meliputi buku-buku dan jurnal-jurnal penelitian hukum baik yang berbentuk fisik maupun hasil dari penelusuran (browsing) internet.

3) Bahan hukum tersier adalah bahan hukum yang memberikan penjelasan mengenai bahan hukum primer dan bahan hukum sekunder, meliputi kamus hukum dan ensiklopedia yang ada kaitannya dengan kajian dalam tesis ini.

Sesuai dengan permasalahan yang ingin dijawab dan tujuan yang ingin dicapai dalam penelitian ini, maka data yang terkumpul baik data primer maupun data sekunder dianalisis secara kualitatif, selanjutnya dideskripsikan untuk menjawab permasalahan dalam penelitian ini.

\section{HASIL DAN PEMBAHASAN}

Penerapan Hukum Terhadap Tindak Pidana Pencurian Dengan Kekerasan Yang Dilakukan Oleh Anak Secara Bersamasama.

Tindak pidana pencurian yang diatur dalam Pasal 365 KUHP sesungguhnya hanyalah satu kejahatan bukan dua kejahatan yang terdiri atas kejahatan pencurian dan kejahatan pemakaian kekerasan terhadap orang.

Tindak pidana yang diatur dalam Pasal 365 KUHP merupakan tindak pidana pencurian dengan unsur-unsur yang memberatkan. Dari perumusan Pasal 365 KUHP dapat menyebutkan unsur-unsur tindak pidana pencurian dengan kekerasan dari ayat (1) sampai dengan ayat (4).Adapun unsurunsurnya sebagai berikut :

Ayat (1) memuat unsur-unsur :

- Pencurian dengan;

- Didahului;

- Disertai;

- Diikuti;

- Oleh kekerasan atau ancaman kekerasan terhadap seseorang.

Unsur-unsur subjektifnya :

- Mempersiapkan atau mempermudah pencurian itu, atau

- Jika tertangkap tangan memberikan kesempatan bagi diri sendiri atau orang lain dalam kejahatan itu.

Pencurian yang diatur dalam Pasal 365 KUHP, yang pada intinya memiliki unsur :

1. Maksud untuk "mempersiapkan pencurian ", yaitu perbuatan kekerasan atau ancaman kekerasan yang mendahului pengambilan barang. 
2. Maksud untuk "mempermudah pencurian, yaitu pengambilan barang dipermudah dengan kekerasan atau ancaman kekerasan..

Ayat (2) memuat unsur-unsur :

1. Unsur barang siapa;

2. Unsur mengambil sesuatu barang;

3. Unsur yang seluruhnya atau sebagian kepunyaan orang lain;

4. Unsur yang dimaksud untuk memiliki secara melawan hukum;

5. Unsur yang didahului, disertai atau diikuti dengan kekerasan atau ancaman kekerasan, terhadap orang dengan maksud untuk mempersiapkan atau mempermudah pencurian atau dalam hal tertangkap tangan untuk mempersiapkan atau mempermudah pencurian atau dalam hal tertangkap tangan untuk memungkinkan melarikan diri sendiri atau peserta lainnya, atau untuk tetap menguasai barang yang dicuri.

6. Unsur jika perbuatan dilakukan pada waktu malam dalam sebuah rumah atau pekarangan tertutup yang ada rumahnya, dijalan umum, atau dalam kereta api atau trem yang sedang berjalan.

7. Unsur perbuatan yang dilakukan oleh dua orang atau lebih dengan bersekutu.

Putusan hakim pada dasarnya tidak dilepaskan dari pembicaraan tentang keadilan, kemanfaatan dan kepastian hukum, hal itu disebabkan karena ketiga unsur yang esensial dalam hukum. Keadilan pada hakikatnya memberikan perlindungan atas hak dan saat yang sama mengarahkan kepada kewajiban sehingga terjadi keseimbangan antara hak dan kewajiban di dalam masyarakat. Dengan keadilan prosedural baru memberikan jaminan kepastian dan ketertiban tetapi belum tentu memberikan keadilan secara substansial. Apabila ketiga unsur tersebut diterapkan sepenuhnya di dalam suatu putusan hakim maka dengan sendirinya putusan tersebut tidak akan melanggar dan menyalahi kepentingan siapapun.

Pengadilan Negeri Makassar yang memberikan dan mengadili perkara pidana dengan terdakwa1.Ian Ramadhan Bin Muhlis bersama terdakwa 2. M. Syahrul Mahpul Bin
Mas Dulhak Alias Ipul Zaenit telah menghadirkan dipersidangan, dan telah dibacakan identitasnya secara lengkap, dengan dakwaan melanggarPasal 365 ayat (2) ke-1 dan ke-2 KUHP danPasal 363 ayat (1) ke-4 KUHP.

\section{Mengadili}

1. Menyatakan terdakwa 1. Ian Ramadhan Bin Muhlis bersama terdakwa 2. M. Syahrul Mahpul Bin Mas Dulhak Alias Ipul Zaenit terbukti secara sah dan meyakinkan bersalah melakukan tindak pidana "Pencurian dengan Kekerasan dalam keadaan memberatkan".

2. Menjatuhkan pidana kepada para terdakwa tersebut oleh karena itu dengan pidana penjara : terdakwa 1 selama 7 (tujuh) bulan dan terdakwa 2 selama 10 (sepuluh) bulan;

3. Menetapkan bahwa masa penahanan yang telah dijalani para terdakwa dikurangkan seluruhnya dari pidana yang dijatuhkan;

4. Memerintahkan agar para terdakwa tetap berada dalam tahanan;

5. Menetapkan barang bukti kepada pemiliknya;

6. Membebankan kepada terdakwa untuk membayar biaya perkara masing-masing sebesar Rp. 2.000,- (dua ribu rupiah);

Demikian diputuskan oleh Hakim Tunggal pada hari selasa tanggal 10 Februari 2015 oleh Suparman Nyompa, SH., MH sebagai Hakim Tunggal, putusan mana diucapkan pada hari itu juga dalam persidangan yang dinyatakan terbuka untuk umum oleh Hakim Tunggal tersebut diatas, dibantu oleh Surhatta, SH sebagai Panitera Pengganti pada Pengadilan Negeri Makassar yang dihadiri oleh Helmy Tambuku, SH sebagai Jaksa Penuntut Umum dan Para terdakwa.

Melihat dari posisi kasus yakni bahwa terdakwa 1.Ian Ramadhan Bin Muhlis bersama terdakwa 2. M. Syahrul Mahpul Bin Mas Dulhak Alias Ipul Zaenit terbukti melakukan tindak pidana pencurian dengan kekerasan pada Pasal 365 ayat (2) ke-1 dan ke-2 KUHP danPasal 363 ayat (1) ke-4 KUHP, dimana unsur-unsur dalam tindak pidana ini sudah memenuhi karakter dan terbukti. 
Faktor-faktor Menjadi Pertimbangan Hakim Dalam Menerapkan Hukum Terhadap Tindak Pidana Pencurian Dengan Kekerasan Yang Dilakukan Oleh Anak Secara Bersama-sama.

Hakim mempunyai kebebasan mandiri dalam mempertimbangkan berat ringannya sanksi pidana penjara terhadap putusan yang ditanganinya. Kebebasan hakim mutlak dan tidak dicampuri oleh pihak lain. Hal ini disebabkan untuk menjamin agar putusan pengadilan benar-benar objektif. Kebebasan hakim untuk menentukan berat ringannya sanksi pidana penjara juga harus berpedoman pada batas maksimum dan minimum serta kebebasan yang dimiliki harus berdasarkan rasa keadilan baik terhadap terdakwa maupun masyarakat da bertanggungjawab terhadap Tuhan Yang Maha Esa.

Setiap putusan pengadilan harus disertai dengan bahan pertimbangan yang memberatkan dan meringankan yaitu :

Hal-hal yang memberatkan :

1. Perbuatan terdakwa dapat meresahkan masyarakat.

2. Perbuatan terdakwa merugikan saksi korban.

Hal-hal yang meringankan :

1. Terdakwa mengakui perbuatannya dan menyesali serta berjanji tidak akan mengulangi lagi perbuatan tersebut.

2. Terdakwa tukang punggung keluarga.

3. Para terdakwa sopan dalam persidangan.

Berdasarkan uraian diatas, dapat dijelaskan bahwa sebelum menetapkan dan menjatuhkan putusan terhadap pelaku tindak pidana pencurian dengan kekerasan yang dilakukan oleh anak secara bersama-sama, terlebih dahulu mempertimbangkan berbagi hal, misalnya fakta-fakta yang terungkap dipersidangan, pertimbangan yuridis dan non yuridis, keadaan dan latar belakang keluarga terdakwa, serta beberapa hal lain yang berhubungan dengan tindak pidana yang dilakukan oleh terdakwa.

Seperti diketahui bahwa hakim diberi fungsi oleh undang-undang untuk menerima, memeriksa, memutuskan dan menyelesaikan perkara yang selalu dituntut untuk emeberikan putusan yang sebenar-benarnya dan seadiladilnya.

Dalam upaya membuat putusan serta memutuskan sanksi pidana, hakim harus mempunyai pertimbangan yuridis yang terdiri dari dakwaan Penuntut Umum, keterangan saksi, keterangan terdakwa, barang bukti, dan pasal-pasal dalam hukum pidana. Adapula pertimbangan non yuridis yang terdiri dari latar belakang perbuatan terdakwa, akibat serta kondisi terdakwa pada saat melakukan perbuatan tersebut.

Hakim anak mendasarkan pembuktiannya terhadap kesalahan terpidana berdasarkan 3 (tiga) alat bukti yang sah yang diatur di dalam Pasal 184 KUHAP, yaitu keterangan saksi, petunjuk, dan keterangan terdakwa. Di dalam memutuskan perkara ini , Hakim Anak mempertimbangkan 2 (dua) saksi, yakni, Najma Nur Mawaddah dan Muh. Ruslan yang pada kesaksiannya menerangkan bahwa para terdakwa memang telah melakukan kejahatan yang diatur dalam Pasal 365 ayat (2) ke-1 dan ke-2 KUHP danPasal 363 ayat (1) ke-4 KUHP.

Mengenai alat bukti petunjuk, hakim anak memperolehnya dengan cara menghubungkan secara logis dan sistematis keterangan para saksi dengan keterangan terdakwa serta barang bukti 1 (satu) buah tas yang berisi dompet warna cream yang isinya 1 (satu) lembar kartu ATM Bank Mandiri Syariah yang berisi uang Rp. 13.000.000, 1 (satu) lembar STNK Motor DD $5457 \mathrm{VZ}$.

Ditinjau dari jumlah alat bukti yang digunakan oleh Penuntut Umum untuk membuktikan kesalahan pelaku, maka putusan tersebut telah memenuhi unsur formil dalam pembuktian berdasarkan Pasal 183 KUHAP yang mengatur bahwa :

"Hakim tidak boleh menjatuhkan pidana kepada seseorang kecuali apabila dengan sekurang-kurangnya dua alat bukti yang sah ia memperoleh keyakinan bahwa suatu tindak pidana benar-benar terjadi dan bahwa terdakwalah yang bersalah melakukannya."

Hakim memang harus menegakkan ketentuan Undang-undang tetapi tidak 
mengesampingkan aspek-aspek lain yang berhubungan dengan suatu tindak pidana ini sudah memenuhi karakter dan terbukti.

\section{KESIMPULAN}

Wujud pemidanaan terhadap tindak pidana pencurian dengan kekerasan yang dilakukan oleh anak secara bersama-sama dengan nomor putusan 10/Pid.Sus Anak/2015/PN.MKS sudah tepat karena telah memenuhi unsur dalam perkara yang didakwakan oleh Jaksa Penuntut Umum dan Majelis Hakim, serta penjatuhan pidana penjara tidak melebihi dari pidana yang diancam oleh Pasal 365 ayat (2) ke-1 dan ke-2 KUHP dan Pasal 363 ayat (1) ke-4 KUHP, dimana unsur-unsur dalam tindak pidana ini sudah memenuhi karakter dan terbukti.

Pertimbangan hukum Hakim dalam menjatuhkan sanksi pidana terhadap anak sebagai pelaku tindak pidana pencurian dengan kekerasan dalam Putusan Nomor :10/Pid.Sus.Anak/2015/PN.Mks yakni dengan terpenuhinya semua unsur-unsur pasal dalam dakwaannya yaitu Pasal 365 ayat (2) ke-1 dan ke-2 KUHP dan Pasal 363 ayat (1) ke-4 KUHP,dimana berdasarkan alat bukti ditambah keyakinan hakim. Selain itu juga hakim dalam menjatuhkan sanksi pidana harus mempertimbangkan hal-hal yang memberatkan dan meringankan bagi terdakwa.

\section{DAFTAR PUSTAKA}

Kapolda JabarPol Irjen M Iriawan, 2015, www.republika.co.id, Diakses pada tanggal 14 April 2015.

Kartono, Kartini, 1992, Patologi Sosial 2. Kenakalan Remaja, Rajawali Pres, Jakarta.

Keraf, Gorys, 2004, Komposisi, Cetakan Ke13, Nusa Indah, NTT.

Marzuki, Peter Mahmud, 2010, Penelitian Hukum, Cetakan Ke-6, Kencana Prenada Media Group, Jakarta.

Salim HS. dan Erlies Septiana Nurbani, 2013, Penerapan Teori Hukum Pada Penelitian Tesis Dan Disertasi, Cetakan Ke-1, Rajawali Pers, Jakarta. Soekanto, Soerjono dan Sri Mamudji, 2013, Penelitian Hukum Normatif, Cetakan
Ke-13, (Jakarta: Rajawali Pers, 2011), hlm.14; Lihat juga Amiruddin dan Zainal Asikin, Pengantar Metode Penelitian Hukum, Cetakan Ke-7, Rajawali Pers, Jakarta.

Soekanto, Soerjono, 2013, Faktor-faktor Yang Mempengaruhi Penegakan Hukum, PT. Raja Grafindo Persada, Jakarta.

Undang-Undang Nomor 11 Tahun 2012 Tentang Sistem Peradilan Pidana Anak.

Undang-Undang Nomor 4 Tahun 1979 tentang kesejahteraan anak

Undang-Undang RI Nomor 35 Tahun 2014 Tentang Perubahan Atas UndangUndang RI Nomor 23 Tahun 2002 Tentang Perlindungan Anak 